\title{
Canopy temperature, excised leaf water retention, productivity and quality of wheat as affected by various nutrient sources in Pearl millet-wheat cropping system
}

\author{
Babli*, Pawan Kumar and R. K. Nanwal \\ Department of Agronomy, CCS Haryana Agricultural University, Hisar-125004 (Haryana), INDIA \\ *Corresponding author. E-mail: bablimamoria@gmail.com
}

Received: May 14, 2016; Revised received: January 25, 2017; Accepted: April 25, 2017

\begin{abstract}
A field experiment was conducted during the year 2013-14 at Agronomy Research Farm of CCS Haryana Agricultural University, Hisar (India). The experiment consisting of twelve treatments was laid out in randomized block design with three replications. Grain yield of pearl millet (3012 kg/ha) was recorded highest in T6 (50\% RD-NP $+50 \% \mathrm{~N}$ through FYM). Yield contributing characters were recorded highest in $\mathrm{T}_{6}(50 \% \mathrm{RD}-\mathrm{NP}+50 \% \mathrm{~N}$ through FYM in pearl millet and $100 \%$ RD-NP in wheat) in wheat crop. In wheat crop, treatment $\mathrm{T}_{6}$ recorded highest growth characters and yield contributing characters. Similarly, highest grain as well as biological yield was recorded in $\mathrm{T}_{6}$. Highest protein content, protein yield, sedimentation value and hectoliter weight was also recorded in $\mathrm{T}_{6}$. Highest grain yield of both pearl millet and wheat $(5582 \mathrm{~kg} / \mathrm{ha})$ in pearl millet-wheat cropping system was obtained with the application of $50 \%$ RD-NP $+50 \% \mathrm{~N}$ through FYM in pearl millet and $100 \%$ RD-NP in wheat while lowest yield of pearl millet (976 kg/ha) and wheat (1190 kg/ha) was recorded in $\mathrm{T}_{1}$ (control).
\end{abstract}

Keywords: Cropping system, INM, NPK, Pearl millet, Wheat

\section{INTRODUCTION}

Pearl millet [Pennisetum glaucum (L)] and Wheat (Triticum aestivum) cropping systems is one of the most prominent and popular cropping system under irrigated conditions in arid and semi-arid areas of India. This system is very exhaustive resulting in decline in productivity and deterioration in soil health. The application of all the needed nutrients through chemical fertilizers has deleterious effect on soil health leading to unsustainable yields. Since, the nutrients turnover in soil-plant system is considerably high under intensive cropping system, so, neither the chemical fertilizers nor the organic sources of nutrients alone can achieve production sustainability of the system. Even with the so called balance use of N, P and $\mathrm{K}$ fertilizers in long term studies, higher yield levels could not be maintained for years because of emergence of secondary and micro-nutrient deficiency and deterioration in the soil physical environment.

Application of organic manure alone or in combination with inorganic fertilizers is known to have favorable effect on soil environment and correct marginal deficiency of secondary and micro-nutrients and enhance efficiency of applied nutrients. It is being realized that system based research on nutrient application would be more advantageous for optimizing the use of different sources of plant nutrients. Therefore, the present study was carried out at Research Farm of
Department of Agronomy, CCS Haryana Agricultural University, Hisar with the objective to study the effect of organic and inorganic sources of nutrients on canopy temperature, excised leaf water retention, productivity and quality of wheat.

\section{MATERIALS AND METHODS}

The experiment was laid out in randomized block design with 12 treatment combinations replicated thrice. The soil of the experimental site was sandy loam in texture, having $\mathrm{pH} 7.87$, poor in available nitrogen $\left(191.53 \mathrm{~kg} \mathrm{ha}^{-1}\right)$, medium in phosphorus $(17.25$ $\left.\mathrm{kg} \mathrm{ha}^{-1}\right)$ and rich in potassium $\left(288 \mathrm{~kg} \mathrm{ha}^{-1}\right)$. The treatments were: $T_{1}$ - Control (no fertilizer); $T_{2}-50$ per cent recommended NP to pearl millet and wheat through fertilizers; $T_{3}-50$ per cent recommended NP to pearl millet and 100 per cent recommended NP to wheat through fertilizers; $\mathrm{T}_{4}-75$ per cent recommended NP to pearl millet and wheat through fertilizers; $T_{5}$ 100 per cent recommended NP to pearl millet and wheat through fertilizers; $\mathrm{T}_{6}-50$ per cent NP through fertilizers +50 per cent $\mathrm{N}$ (farmyard manure) to pearl millet and 100 per cent NP to wheat through fertilizers; $\mathrm{T}_{7}-75$ per cent NP through fertilizers +25 per cent $\mathrm{N}$ (farmyard manure) to pearl millet and 75 per cent NP to wheat through fertilizers; $\mathrm{T}_{8}-50$ per cent $\mathrm{NP}+50$ per cent $\mathrm{N}$ (wheat straw) to pearl millet and 100 per cent NP to wheat through fertilizers; $T_{9}-75$ per cent $\mathrm{NP}+25$ per cent $\mathrm{N}$ (wheat straw) to pearl millet and 
75 per cent NP to wheat through fertilizers; $\mathrm{T}_{10}-50$ per cent NP +50 per cent N (Sesbania spp.) to pearl millet and 100 per cent NP to wheat through fertilizers; $\mathrm{T}_{11}-75$ per cent $\mathrm{NP}+25$ per cent $\mathrm{N}$ (Sesbania spp.) to pearl millet and 75 per cent NP to wheat through fertilizers and $\mathrm{T}_{12}$-farmers' practice.

The recommended levels of nitrogen and phosphorus were 125 and $62.5 \mathrm{~kg} \mathrm{ha}^{-1}$ for pearl millet and 150 and $60 \mathrm{~kg} \mathrm{ha}^{-1}$ for wheat. The pearl millet variety used was HHB 197 with $5 \mathrm{~kg}$ seed ha ${ }^{-1}$, keeping row spacing of $45 \mathrm{~cm}$. In wheat, variety WH 711 was sown with 125 $\mathrm{kg}$ seed ha ${ }^{-1}$ keeping row spacing of $20 \mathrm{~cm}$. The nitrogen content in different organic materials was determined each year and the amount of these materials required for substituting a specified amount of nitrogen as per the treatment was calculated. The organic sources of nutrients viz., FYM, green manure of ses- bania and wheat straw were incorporated in soil at 30 , 36 and 30 days, respectively, before sowing of pearl millet crop. According to the package of practices of CCS Haryana Agricultural University, Hisar (2012), recommended nitrogen $(125 \mathrm{~kg} / \mathrm{ha}$ and $150 \mathrm{~kg} / \mathrm{ha})$ and phosphorus $(62.5 \mathrm{~kg} / \mathrm{ha}$ and $60 \mathrm{~kg} / \mathrm{ha})$ were applied through urea and diammonium phosphate (DAP) in pearl millet and wheat, respectively. One post sowing irrigation was applied during pearl millet. Similarly, in wheat five irrigations were applied. Recommended package of practices of HAU were followed in both the crops for other agronomic operations.

\section{RESULTS AND DISCUSSION}

Pearl millet yield studies: It is clear that highest yield was obtained in $\mathrm{T}_{6}(3012 \mathrm{~kg} / \mathrm{ha})$ and at par with $\mathrm{T}_{5}$ (2935 kg/ha) recoded $209 \%$ higher grain yield over

Table 1. Effect of different nutrient treatments on grain and stover yield $(\mathrm{kg} / \mathrm{ha})$ of pearl millet.

\begin{tabular}{|c|c|c|c|c|}
\hline \multirow{2}{*}{$\begin{array}{l}\text { Treat- } \\
\text { ments }\end{array}$} & \multicolumn{2}{|c|}{ Seasons } & \multirow[t]{2}{*}{ Grain yield } & \multirow[t]{2}{*}{ Stover yield } \\
\hline & Kharif & Rabi & & \\
\hline $\mathrm{T}_{1}$ & Control (no fertilizer) & Control (no fertilizer) & 976 & 2244 \\
\hline $\mathrm{T}_{2}$ & $50 \%$ rec. $\mathrm{N}$ and $\mathrm{P}$ through fertilizers & $50 \%$ rec. $\mathrm{N}$ and $\mathrm{P}$ through fertilizers & 1814 & 4262 \\
\hline $\mathrm{T}_{3}$ & $50 \%$ rec. $\mathrm{N}$ and $\mathrm{P}$ through fertilizers & $100 \%$ rec. $\mathrm{N}$ and $\mathrm{P}$ through fertilizers & 1932 & 4675 \\
\hline $\mathrm{T}_{4}$ & $75 \%$ rec. $\mathrm{N}$ and $\mathrm{P}$ through fertilizers & $75 \%$ rec. $\mathrm{N}$ and $\mathrm{P}$ through fertilizers & 2412 & 5861 \\
\hline $\mathrm{T}_{5}$ & $100 \%$ rec. $\mathrm{N}$ and $\mathrm{P}$ through fertilizers & $100 \%$ rec. $\mathrm{N}$ and $\mathrm{P}$ through fertilizers & 2935 & 7337 \\
\hline $\mathrm{T}_{6}$ & $\begin{array}{l}50 \% \text { rec. } \mathrm{N} \text { and } \mathrm{P} \text { through fertilizers }+ \\
50 \% \mathrm{~N} \text { through } \mathrm{FYM}\end{array}$ & $100 \%$ rec. $\mathrm{N}$ and $\mathrm{P}$ through fertilizers & 3012 & 7831 \\
\hline $\mathrm{T}_{7}$ & $\begin{array}{l}75 \% \text { rec. } \mathrm{N} \text { and } \mathrm{P} \text { through fertilizers }+ \\
25 \% \mathrm{~N} \text { through FYM }\end{array}$ & $75 \%$ rec. $\mathrm{N}$ and $\mathrm{P}$ through fertilizers & 2704 & 6651 \\
\hline $\mathrm{T}_{8}$ & $\begin{array}{l}50 \% \text { rec. } \mathrm{N} \text { and } \mathrm{P} \text { through fertilizers }+ \\
50 \% \mathrm{~N} \text { through wheat straw }\end{array}$ & $100 \%$ rec. $\mathrm{N}$ and $\mathrm{P}$ through fertilizers & 2824 & 7003 \\
\hline $\mathrm{T}_{9}$ & $\begin{array}{l}75 \% \text { rec. } \mathrm{N} \text { and } \mathrm{P} \text { through fertilizers }+ \\
25 \% \mathrm{~N} \text { through wheat straw }\end{array}$ & $75 \%$ rec. $\mathrm{N}$ and $\mathrm{P}$ through fertilizers & 2472 & 6031 \\
\hline $\mathrm{T}_{10}$ & $\begin{array}{l}50 \% \text { rec. } \mathrm{N} \text { and } \mathrm{P} \text { through fertilizers }+ \\
50 \% \mathrm{~N} \text { through green manure }\end{array}$ & $100 \%$ rec. $\mathrm{N}$ and $\mathrm{P}$ through fertilizers & 2841 & 7074 \\
\hline $\mathrm{T}_{11}$ & $\begin{array}{l}75 \% \text { rec. } \mathrm{N} \text { and } \mathrm{P} \text { through fertilizers }+ \\
25 \% \mathrm{~N} \text { through green manure }\end{array}$ & $75 \%$ rec. $\mathrm{N}$ and $\mathrm{P}$ through fertilizers & 2575 & 6308 \\
\hline $\mathrm{T}_{12}$ & $\begin{array}{l}\text { Farmers' practice }=(\mathrm{N}, \mathrm{P}=49.125, \\
15.175 \mathrm{~kg} / \mathrm{ha}) \\
\mathrm{FYM}=37.8 \mathrm{q} / \mathrm{ha} .\end{array}$ & $\begin{array}{l}\text { Farmers practice }=(\mathrm{N}, \mathrm{P}, \mathrm{K}=156.25 \\
58.575,3.7 \mathrm{~kg} / \mathrm{ha}) \\
\mathrm{FYM}=25.1 \mathrm{q} / \mathrm{ha} \\
\mathrm{ZnSO}_{4}=8.4 \mathrm{~kg} / \mathrm{ha}\end{array}$ & 2768 & 6836 \\
\hline \multirow{2}{*}{\multicolumn{3}{|c|}{$\mathrm{SEm} \pm$}} & 29.3 & 77.7 \\
\hline & \multicolumn{2}{|c|}{$\mathrm{CD}(\mathrm{P}=0.05)$} & 86.4 & 229.4 \\
\hline
\end{tabular}

Table 2. Effect of different nutrient sources on the yield contributing characters and yield of wheat.

\begin{tabular}{|c|c|c|c|c|c|}
\hline Treatments & $\begin{array}{c}\text { Plant height at } \\
\text { Maturity }\end{array}$ & $\begin{array}{c}\text { Effective } \\
\text { tillers/mrl }\end{array}$ & $\begin{array}{l}\text { 1000-grain } \\
\text { weight (g) }\end{array}$ & $\begin{array}{c}\text { Biological } \\
\text { yield(kg/ha) }\end{array}$ & $\begin{array}{c}\text { Grain } \\
\text { yield (kg/ha) }\end{array}$ \\
\hline $\mathrm{T}_{1}$ & 52.7 & 65.0 & 34.8 & 2499 & 1190 \\
\hline $\mathrm{T}_{2}$ & 81.7 & 90.1 & 42.1 & 7798 & 3610 \\
\hline $\mathrm{T}_{3}$ & 83.3 & 92.7 & 44.3 & 9902 & 4649 \\
\hline $\mathrm{T}_{4}$ & 85.3 & 91.8 & 43.1 & 9836 & 4640 \\
\hline $\mathrm{T}_{5}$ & 94.0 & 99.0 & 49.7 & 12050 & 5490 \\
\hline $\mathrm{T}_{6}$ & 94.6 & 100.3 & 50.0 & 12269 & 5582 \\
\hline $\mathrm{T}_{7}$ & 91.2 & 95.2 & 46.7 & 10877 & 5036 \\
\hline $\mathrm{T}_{8}$ & 92.3 & 97.5 & 47.7 & 11176 & 5127 \\
\hline $\mathrm{T}_{9}$ & 87.4 & 93.4 & 45.6 & 10147 & 4742 \\
\hline $\mathrm{T}_{10}$ & 93.8 & 98.7 & 48.9 & 11871 & 5421 \\
\hline $\mathrm{T}_{11}$ & 88.5 & 94.1 & 46.1 & 10210 & 4749 \\
\hline $\mathrm{T}_{12}$ & 92.0 & 96.3 & 45.0 & 11034 & 5085 \\
\hline $\mathrm{SEm} \pm$ & 2.1 & 0.5 & 1.1 & 43.4 & 16.0 \\
\hline $\mathrm{CD}(\mathrm{P}=0.05)$ & 6.1 & 1.6 & 3.3 & 128.2 & 47.3 \\
\hline
\end{tabular}


Table 3. Effect of organic and inorganic nutrient sources on canopy temperature $\left({ }^{\circ} \mathrm{C}\right)$ and excised leaf water retention at earing $(\%)$ of wheat.

\begin{tabular}{lcc}
\hline Treatments & $\begin{array}{c}\text { Canopy } \\
\text { Temperature }\end{array}$ & $\begin{array}{c}\text { Excised leaf water } \\
\text { retention at earing }\end{array}$ \\
\hline $\mathrm{T}_{1}$ & 25.3 & 57.2 \\
$\mathrm{~T}_{2}$ & 24.5 & 61.3 \\
$\mathrm{~T}_{3}$ & 23.7 & 69.2 \\
$\mathrm{~T}_{4}$ & 23.7 & 67.4 \\
$\mathrm{~T}_{5}$ & 24.5 & 82.5 \\
$\mathrm{~T}_{6}$ & 23.1 & 83.2 \\
$\mathrm{~T}_{7}$ & 23.7 & 74.2 \\
$\mathrm{~T}_{8}$ & 24.3 & 76.8 \\
$\mathrm{~T}_{9}$ & 24.6 & 71.3 \\
$\mathrm{~T}_{10}$ & 24.0 & 81.4 \\
$\mathrm{~T}_{11}$ & 24.8 & 73.1 \\
$\mathrm{~T}_{12}$ & 23.7 & 76.2 \\
$\mathrm{SEm} \pm$ & 0.3 & 0.5 \\
$\mathrm{CD}(\mathrm{P}=0.05)$ & 0.8 & 1.5 \\
\hline
\end{tabular}

control (Table 1) and significantly better over rest of the treatments. The higher grain yield of pearl millet obtained with 100\% RD-NP and $50 \%$ RD-NP $+50 \%$ $\mathrm{N}$ through FYM in pearl millet could be ascribed to their favourable effects on yield (Table 1). Stover yield was also recorded highest in $\mathrm{T}_{6}(7831 \mathrm{~kg} / \mathrm{ha})$. Grain and straw yield also increased with higher dose of inorganic fertilizers. This might be due to easy availability of plant nutrients and higher photosynthetic activities as compared to under dose fertilized treatments. The results are in conformity with those of (Kumar Pawan et al., 2012) reported that in total production of the system only FYM could replace $50 \%$ nitrogen need of pearl millet without much adverse effect on its production.

The increased availability of $\mathrm{P}$ increased the growth and yield attributing characters which reflected in higher yield of pearl millet. Grain and stover yield were recorded better in treatments where $\mathrm{N}$ was supplied through FYM and green manure, as to that of wheat straw. This may be due to higher $\mathrm{C}: \mathrm{N}$ in wheat straw at initial growth period of the crop. The findings are similar in $\mathrm{T}_{6}(50$ per cent NP through fertilizers + 50 per cent $\mathrm{N}$ (farmyard manure) to pearl millet and
100 per cent NP to wheat through fertilizers) in pearl millet and wheat cropping system (Kumar et al., 2012).

Wheat growth characters: In general, the growth characters of wheat were superior due to favourable weather conditions. Growth and development is a physiological phenomenon of plant life. The rate and amount of growth has a very considerable effect on ultimate yield of the plant. Plant height and dry matter increased at a slow rate up to $60 \mathrm{DAS}$, thereafter; they increased at faster rate upto 120 DAS. $50 \%$ RD-NP + $50 \% \mathrm{~N}$ through FYM in pearl millet and $100 \% \mathrm{RD}$ NP in wheat, showed the beneficial effect on the plant height at maturity (Table 2). Besides, its role in chlorophyll synthesis, nitrogen plays an important role in cell division and cell enlargement. Nitrogen inside the plant control the synthesis of body building materials, obviously the deposition of protoplasmic constituents in the cells and higher hydration ratio affected by nitrogen nutrition might have increased the turgidity of the elongated cells. This could have brought an increase in growth and development of plants which ultimately affected the height and dry matter positively. These findings are in confirmation with $\mathrm{T}_{6}[50$ per cent NP through fertilizers +50 per cent $\mathrm{N}$ (farmyard manure) to pearl millet and 100 per cent NP to wheat through fertilizers](Kumar, 2010) in pearl millet and wheat cropping system.

Pronounced response obtained through the application of FYM in growth characters might be attributed primarily to the enriched supply of essential nutrients and enhanced availability of native phosphorus. The $\mathrm{CO}_{2}$ produced during the mineralization of organic matter play important role in the solubilisation of native phosphorus. The poor performance of wheat straw in comparison to FYM and green manure might be due to the immobilization of nitrogen in the rhizosphere and thus consumption of more energy for the decomposition of cellulose, hemicelluloses and legnin parts in straw. Poor performance of wheat was mainly because of immobilization in wheat straw applied plots.

Yield contributing characters: Economic yield of

Table 4. Effect of different treatments on quality characters of wheat grain.

\begin{tabular}{lcccc}
\hline Treatments & Protein content (\%) & Protein Yield (kg/ha) & Sedimentation value (ml) & Hectolitre weight (hl) \\
\hline $\mathrm{T}_{1}$ & 7.8 & 92.8 & 26.3 & 76.2 \\
$\mathrm{~T}_{2}$ & 7.8 & 281.6 & 28.0 & 77.2 \\
$\mathrm{~T}_{3}$ & 7.9 & 367.3 & 30.3 & 77.7 \\
$\mathrm{~T}_{4}$ & 7.8 & 361.9 & 28.3 & 77.5 \\
$\mathrm{~T}_{5}$ & 8.1 & 444.7 & 34.0 & 79.1 \\
$\mathrm{~T}_{6}$ & 8.2 & 457.7 & 35.3 & 79.2 \\
$\mathrm{~T}_{7}$ & 7.9 & 397.8 & 32.3 & 78.3 \\
$\mathrm{~T}_{8}$ & 8.0 & 410.2 & 32.7 & 77.8 \\
$\mathrm{~T}_{9}$ & 7.8 & 369.8 & 30.7 & 79.0 \\
$\mathrm{~T}_{10}$ & 8.0 & 433.7 & 33.7 & 78.0 \\
$\mathrm{~T}_{11}$ & 7.8 & 370.4 & 32.3 & 78.7 \\
$\mathrm{~T}_{12}$ & 7.9 & 401.7 & 32.6 & 0.3 \\
$\mathrm{SEm} \pm$ & 0.01 & 8.16 & 0.5 & 0.9 \\
$\mathrm{CD}(\mathrm{P}=0.05)$ & 0.03 & 23.57 & 1.3 & \\
\hline
\end{tabular}


crop plants depends on the source-sink relationship and on different components of the sink itself viz., effective tillers $\mathrm{m}^{-1}$ and 1000 grain weight. Source includes the functional leaves, tillers and dry matter of the plant before anthesis.

Yield components viz., tillers $\mathrm{m}^{-1}$, length of spike, grains per spike and 1000-grain weight were found higher when $50 \% \mathrm{RD}-\mathrm{NP}+50 \% \mathrm{~N}$ through FYM in pearl millet and $100 \%$ RD-NP in wheat. This could be attributed to the supply of most of the required macro and micro nutrients in adequate amount for a long time due to slow release of nutrients by the FYM. These findings are in close conformity with that of (Kumar et al., 2014) in pearl millet and wheat cropping system.

Yield studies: Grain yield increased with the application of fertilizer upto recommended dose (Table2). $\mathrm{T}_{6}$ produced $369 \%$ higher yield over control, $55 \%$ over $\mathrm{T}_{2}(50 \% \mathrm{RD}-\mathrm{NP}$ in pearl millet and $100 \% \mathrm{RD}-\mathrm{NP}$ in wheat). The above findings can be explained on the basis of the fact that nitrogen being a constituent of protoplasm increased the photosynthetic products and meristematic activities. Organic manures supplied the adequate and continuous amount of nutrients at different stages due to release of significant amount of nutrients by mineralization at a constant level that resulted in highest grain yield. The beneficial effect of fertilizer on grain yield and its attributes have been reported by (Sammauria and Yadav, 2008) in fenugreek and pearl millet. Highest grain yield was recorded in $T_{6}(5582$ $\mathrm{kg} / \mathrm{ha}$ ). The higher grain yield in $\mathrm{T}_{6}$ was being supported by different yield contributing characters. Yield contributing characters viz., effective tillers per meter row length and 1000-grain weight were recorded higher in $\mathrm{T}_{6}$, which were $54 \%$ and $44 \%$ higher over control, respectively. The results are in confirmation to the findings of Kumar et al. (2012) in cereal-cereal cropping sequence. Phosphorus application might have shown significant effect on the yield of the wheat. This might be attributed to its beneficial effect on yield attributes, higher availability of $\mathrm{P}$ that promoted growth and development, and ultimately resulting in higher yield. These findings are in confirmation of Sammauria and Yadav (2008).

Fertilizer caused pronounced effect on growth parameters, yield attributes and finally on the grain and biological yield of wheat crop. Higher biological yield were recorded in $\mathrm{T}_{6}$. This might be attributed to the better growth of plant, which in turn resulted in significant plant height $(94.6 \mathrm{~cm})$ resulting into higher biological yield. It was found that there was no significant difference in grain yield of wheat recorded at $100 \%$ RD-NP and the treatment where nitrogen was substituted through FYM in pearl millet followed by $100 \%$ RD-NP in wheat. This might be attributed to availability of nitrogen for entire growing season due to slow mineralization of organic nitrogen from FYM in pearl millet-wheat cropping system.
Canopy temperature: A careful view of data in Table 3 indicate that low canopy temperature was recorded in $\mathrm{T}_{6}\left(23.1{ }^{0} \mathrm{C}\right)$ which is statistically at par with all other treatments except $\mathrm{T}_{1}$ (control), where highest canopy temperature was recorded $\left(25.3{ }^{\circ} \mathrm{C}\right)$.

Excised leaf water retention at earing: The data on excised leaf water as influenced by different sources of nutrient presented in Table 3 indicate that higher excised leaf water retention was recorded in $\mathrm{T}_{5}(82.5 \%)$ among the chemical fertilizer treatments, where as in integrated nutrient sources $\mathrm{T}_{6}(83.2 \%)$ recorded highest excised leaf water retention which is higher over all other treatments. $\mathrm{T}_{6}(83.2 \%)$ and $\mathrm{T}_{5}(82.5 \%)$ were statistically at par with each other in excised leaf water retention.

Quality studies: Protein is an important functional quality character for making different products of wheat like good chapatti, bread and biscuits. Protein content and protein yield (Table 4) increased with addition of inorganic fertilizer and highest were recorded when $100 \%$ RD-NP was applied to both pearl millet and wheat through chemical fertilizers. Among all the treatment integrated nutrient management treatments $\mathrm{T}_{6}$ where $50 \% \mathrm{~N}$ was supplemented through FYM in pearl millet and $100 \%$ RD-NP in wheat recorded highest protein content and protein yield of wheat. This is because of $\mathrm{N}$ increased the protein content and protein yield.

Sedimentation value is the index of glutin strength, higher the value, better the quality of wheat. Sedimentation values were highest at $100 \%$ RD-NP and with FYM application in pearl millet and $100 \%$ RD-NP in wheat but at par with $100 \% \mathrm{RD}-\mathrm{NP}$ in both crops. It is supported by the findings of (Kumar et al., 2008).

Hectolitre weight is an important parameter for millers, as it is positively co-related with flour recovery. Higher the hectolitre weight, higher will be flour recovery. Hectolitre weight was computed maximum with the application of FYM.

\section{Conclusion}

The study clearly revealed that highest grain yield of both Pearl millet (3012 kg/ha) and wheat $(5582 \mathrm{~kg} / \mathrm{ha})$ in pearl millet-wheat cropping system was obtained with the application of $50 \%$ recommended dose of Nitrogen and Phosphorus $+50 \%$ Nitrogen through Farm Yard Manure in pearl millet and $100 \%$ recommended dose of Nitrogen and Phosphorus in wheat. Highest protein content $(8.2 \%)$, protein yield (457.7 $\mathrm{kg} / \mathrm{ha})$, sedimentation value $(35.3 \mathrm{ml})$ and hectoliter weight $(79.2 \mathrm{hl})$ was also recorded in this treatment.

\section{REFERENCES}

Kumar, Pawan, Yadav, S. K., Kumar, Manoj and Nanwal, R. K. (2012). Effect of integrated nutrient management on crop productivity and soil health under cereal-cereal 
cropping sequence. Haryana J. Agron., 28: 50-52

Kumar, Pawan, Kumar, Manoj, Yadav, S. K. and Nanwal, R. K. (2014). Agronomic management for sustainable pearlmillet-wheat cropping systems in sandy loam soils. Ann. Agri. Res. New Series, 35: 304-310

Kumar, Amit, (2010). Response of pearlmillet-wheat cropping system to various sources of nutrients in terms of growth, yield and nutrient uptake M.Sc Thesis, CCS HAU, Hisar.
Kumar, Pawan, Yadav, S. K., Kumar, Manoj, Hasija, R. C. and Pahuja, S. S. (2008). Enhancing income from pearl millet-wheat cropping system through the use of Farm yard manure and crop management techniques. Environ and Ecol., 26: 1649-51

Sammauria, R. and Yadav, R. S. (2008). Effect of phosphorus and zinc application on growth and yield of fenugreek and their residual effect on succeeding pearl millet. Indian J Agric Sci., 78: 61-64 